\title{
Instead of a Conclusion
}

"How could that happen to me?" More than two decades have passed after the key scene at the Armanen-Orden's Ostara Thing described at the very beginning of my introduction, which led to this question. During this entire period, my work on Germanic Neopaganism was motivated and guided by the righteous indignation spurred by such moments of disillusion. Twenty-five years later, I am still driven by it, but something has changed as well. Three experiences from my research round between 2010 and 2012 capture this change.

(1) It is around Easter 2010, and Ostara is still popular amongst German Heathens. I am invited to a castle turned youth hostel to celebrate this fictional goddess and the arrival of spring once again. The invitation was extended to me after I conducted the first interviews with members of the German a-racist Eldaring. After considerable apprehension from both sides, a dialogue had been established. I am to speak at the event, to give a talk about Heathens' concepts of religion, putting forth the argument that is now developed in Chapter 5. I was hesitant to put myself in a situation where I had to talk about my research in front of my research subjects, but I finally decided that I wanted to meet this challenge head on. The talk seems to go well, the ensuing discussion is open, lively. We do not agree on every point; to the contrary. But I am impressed by my audience's openness and willingness to reflect on their own positions. Afterwards I receive compliments for my courage to "enter the lion's den."

Later that evening, I realize that my ambivalence around these Asatruers is still there, as is their defensiveness. At the dinner table I have a peculiar encounter with a young man, who tries somewhat frantically to convince me that they could not possibly be right-wingers. I am somewhat puzzled by this unsolicited revelation. Later on, when I see the selection of books for sale at the event, I begin to understand this defensiveness: there are a number of titles that clearly hark back to a völkisch tradition. The duplicity that characterizes Germanic Neopaganism is still there, and yet my main impression remains that something in the atmosphere has changed. There is an increased openness and friendliness, and the defensiveness is less aggravated, at least in this and other a-racist groups. They seem to cherish their friendships and their community more than they need to insist on their status as ostracized outsiders.

(2) I am sitting in a spacious meadow somewhere in Northern Germany. I am surrounded by young people and families; there are about twenty people hanging out on the grounds of an old farmhouse that now serves as a modest group retreat

(C) KONINKLIJKE BRILL NV, LEIDEN, 2016 | DOI 10.1163/9789004309517_012

This is an open-access article distributed under the terms of the Creative Commons Attribution-

NonCommercial 3.o. Unported (CC BY-NC 3.o) License, http://creativecommons.org/licenses/by-nc/3.0/ 9789004309517 
and self-catering seminar center. The day before has been spent in preparation of an elaborate self-designed ritual involving an anonymous gift exchange. We were all supposed to bring an object that was meaningful to us, but that we were also ready to part with. I had brought a small crystal cube with a carving of a koala bear inside, the type you get at souvenir stores all over the world. This one was given to my by an Australian Odinist whom I had met in California a few years earlier. I had kept it on my desk since then as reminder of my ambivalent involvement with Asatru. It seems like a good time to part with it, to pass it on. During the ritual we weave and knot together numerous strands of multicolored fabric into a convoluted web. There is chatter and laughing and sighs of exasperation. We have moved in a circle, or maybe rather in an elipse, then in a spiral. The gifts have been gathered in a large sack, and at the end of the ritual we each draw one. I end up with a small, dome-shaped bluish rock, covered in dots and ridges like those of a fossil. A part of the top and one of its sides is broken off, revealing a smooth, marble-like inside. It has now replaced the crystal on my desk and reminds me of my journey of discovery within Asatru - a journey which has involved the violent breaking away of petrified layers of defense, and the uncovering of equally petrified and persistent remnants of völkisch thought, along with unexpected discoveries.

Yet another one of those unexpected, memorable events takes place in the afternoon of the same day. The small group Nornirs Att is gathering for its annual meeting - an event that combines a decision-making assembly with ritual. I am invited to participate as a non-member, which is a rare event. After long discussions about members, workshops, offices, and responsibilities, a surprise topic is called. A long-term member of the group stands up and talks about the book I published in 1992. He recalls how a bunch of rather unorganized but enthusiastic Pagans set out in the early nineties to rid the scene of its racial esoteric and völkisch ideological baggage. He says, "Sure, we could have done this research on our own and completed the process independently. But this book has certainly saved us a lot of time and effort." With a grand gesture he raises a drinking horn and offers it to me as a gift, honoring my contribution to Asatru's turn towards respectability. I am flabbergasted and a little flattered. I accept the gift in a manner I hope is somewhat graceful and am honestly moved. In a flash, I realize how complicated my relationship to these 'reform-Asatruers' really is. Sure enough, this gesture can be construed as a calculated move to forestall my fundamental critique. But I sense an honest connection between their wish to live as decent, politically reflective, and observant human beings, while following their Neopagan convictions and appreciating my attempts to enlighten them as to the scene's involvement with right-wing machinations.

(3) A year and a half later I have finished my manuscript and am working on my proposal, with this last chapter yet to be written. I am sitting at lunch with a 
younger colleague, who is a medievalist. I tell her that there is one fundamental question this book project has not been able to resolve, and that leaves me ambivalent. I feel torn between two forces. On the one hand, I harbor sympathy towards many of the younger a-racist Heathens, the metal fans, and the enthusiastic admirers of myth and ancient religions and rituals. On the other hand, I cannot let go of this deep-seated unease in face of the circulating discourse on Norse myth, with all its ideological ballast. My colleague exclaims, "I know the feeling, I know it exactly." She is one of the few medievalists who share my opinion that attempts to reconstruct any kind of pre-Christian Norse thought, religion, or culture are futile and methodologically flawed, hence her deep skepticism. But I am amazed that she shares the sense of sympathy that I feel, and that she agrees that many of her students who harbor an enthusiastic interest in reconstructionist approaches, and also practical aesthetic engagements with Norse myth, are intelligent, deliberate, and engaged people. After a while, we come to the conclusion that it is impossible to resolve the contradiction and eliminate the feeling of being torn.

I realize now that all I have done in the chapters of this book was to circle around and to explore this ambivalence, to look for clues, for possibilities of distinction, and for clear-cut delineations. I have not been able to pinpoint them clearly. Rather, I have performed them over and over again in various contexts. It could be that the not-quite resolved oscillation between an ideologically critical discourse analysis and hermeneutic approaches that run through the argumentation of this book has to do with these ambivalences.

These three instances show how intricately interwoven my work has been with the Germanic Neopagan communities I have researched. The honoring of my book by younger Asatruers has made it clear to me that my work has had a very real impact, at least on the struggles within German Asatru. In my earlier books I focused on the Armanen-Orden and its affiliates, which alerted other Pagans to their racial-esoteric agenda. It also gave them an easy target, and the chance to distance themselves and their own groups from racist thought by simply rejecting the Armanen-Orden and its teachings. The existence of my book might have kept groups like the Armanen-Orden and the Germanische Glaubensgemeinschaft at the center of attention much longer than their actual influence in the scene lasted, while other, equally complicated strands of thought were less scrutinized.

The influence has been mutual. Reflecting on these encounters now, I realize how much they have changed me. They have provided me with new answers to my question, "how could this happen to me?" During my interviews and conversations, I have felt time and again that I do in fact share interests and desires with some Asatruers. The surprise during my research process 
was indeed that I am not the only one to criticize Asatru as potentially ethnicist and culturally essentialist, while simultaneously acknowledging its continual creative productivity. Some Asatruers actually harbor similar sentiments and concerns.

This acknowledgment of a kinship with some of my research subjects carries with it a certain disappointment. My book has turned out to be much less sensationalist and not as immediately politically urgent as I had intended it to be. What this does give me, however, is space to look, to listen, to explore, and to find the more subtle connections between Asatru and the fields of discourse, ideas, and topics that are dear to me, such as feminist and queer theory, ecology, art and literature, and scholarly discourse. Thus, my own person, my own thought, is involved in the field that I research to a much larger degree. In my previous work, I tried to distance myself from the scene by demarcating my investigative position. However, lines of connection between myself and my subject began emerging more frequently. My encounters with Asatruers have made this sense of connection more concrete, anchoring it in lived experience. Seeing and meeting people who ask themselves questions that resemble those I am asking makes for a changed dynamic. Also, it changes my perspective in a way that brings my own thinking into focus, and not just the thoughts of 'others.'

The initial motive that drove my research in the 1980s was to show the world how dangerous a religion that bases itself on racial-esoteric ideas could become. Implicit in my research was the wish to 'rescue' that which was 'good' and 'untainted' within the discourse of Nordic myth, which had become fascinating for me during my studies of medieval and modern Scandinavian literature. It was the same motivation that leads many of my students to choose Scandinavian studies as a field today as well.

From the 1990s onwards, my desire to identify areas that employed discourses on (Nordic) myth, but were untainted by ethnic or cultural essentialism, was continually disappointed. This process of disillusionment with alternative religion, feminism and feminist spirituality, ecology, and, finally, my own academic fields of Scandinavian and literary studies is mirrored in the chapters of this book. Increasingly, the realization that there is no clear-cut outside to this problematic discourse reshaped my own position as a researcher. More than ever before, during my most recent field studies, conducted between 2008 and 2012, I met Asatruers who seemed to be considerably more informed about and critical toward the problems inherent in a naïve application of Old Icelandic and ancient sources to contemporary religion than their contemporaries from other alternative religions or social movements. Conversations with non-specialists who asked about my work showed something else as well: 
namely that a strong cultural essentialism, unfounded assumptions about the age of Nordic myths, and the survival of these myths in modern customs and tales are all deeply ingrained in common perceptions of 'the Nordic', and reach far beyond the Asatru community. The Romantic paradigm is still very much alive. These shared ideas are strongly related to a broader tendency, which I have described as the conflation of ethnicity, culture, and religion, or, the culturalization of religion and the sacralization of culture and ethnicity. This kind of new holism, the assumption that there is an uncomplicated continuity between heritage, culture, land, climate, and spirituality, has become naturalized again in recent years. It appears as almost a matter of fact in parts of mainstream discourse. In this context, 'culture' indeed acquires a function that 'race' held previously, connoting an essence that has to be 'preserved' and 'kept pure.'

While I continually point to the perpetuation of ethnicist or völkisch thought in and beyond Asatru, I am also aware that this thinking can be changed. These ideas are intertwined with contemporary concerns, attitudes, and discourses, and they are employed in order to make sense of a contemporary world. It is thus not the purpose of this book to label all individuals who are fascinated with Asatru or the world of Nordic myth as 'racists.' My critique is in fact rarely directed against individuals. Rather, my interest has been to show that certain religious or reconstructionist attitudes have racist, ethnicist, or cultural essentialist implications. Their critical analysis is necessary, as reconstructionism can prove fecund for politics of exclusion and domination. As George S. Williamson wrote in the conclusion to his analysis of The Longing for Myth in Germany in the 19th century, the discourse on myth tended to "harden already existing divisions of class, religion, and ethnicity. In doing so, [it] ignored not only the potential for human communities that crossed such lines but the very possibility of meaningful cultural transfer or translation from one epoch, nation or 'race' to another."

Ethnicist, cultural essentialist, and racist ideas are indeed closely intertwined with the history of my field and my own academic predilections. Scandinavian studies, Germanic studies, and Indo-European studies have all contributed to the formation of the discourse which has been fashioned into religion by Asatruers, and to which they remain attached today. It is therefore no wonder that some of my colleagues in Scandinavian studies, as well as my students, seem to find it hard to let go of the desire to reconstruct pre-Christian Nordic or Germanic beliefs, mentality, and culture - at the price of neglecting the fascinating political, theological, and literary connections between the

1 Williamson, The Longing for Myth in Germany, 299. 
North and the rest of the continent during the High Medieval Period. As much as both sides hate to acknowledge this kinship, Asatru and reconstructive Old Norse studies remain connected by the desire to reconstruct pre-Christian religion, culture, thought, and practice.

Two questions remain to be addressed:

(1) What constitutes the ongoing attraction of the discourse on Nordic myth?

At its core, it comes down to the combination of the thrill of exoticism and the safety of familiarity or alleged ownership. The imagined return to 'the old Gods,' to 'the gods of the ancestors,' implies that the 'innocent native,' the 'noble savage,' and the 'repressed origin' are located not in a repressed other, but in the individual itself. Identifying with these positions implies that one is not a perpetrator or profiteur of imperial conquest, colonial despotism, or violent proselytizing. Rather, one counts oneself among those subject to cultural extinction. Thus, the drive toward Asatru is as much an identification with a position of innocent victimhood, which supposedly relieves one of historical guilt, as it is a fantasy of superiority. This speculation leads to the second core question:

(2) Where does the acute defensiveness and awareness of Asatruers with regard to their religion and its ideological implications come from?

Although their defensiveness is exacerbated by outside allegations of National Socialist sympathies, such outside attacks are not the only, and probably not even the core, reason. It rather seems to be a more or less conscious unease with the political, ethical, or ideological implications of neoGermanic religion, which are based on a Romantic fiction of unity, wholeness, and origin. From this defensive and precarious position stem the numerous attempts to 'purify' Asatru, a desire that manifests itself on many different levels. Most prominent is the desire to rid oneself of Christian elements or influences, along with any völkisch ones, as well as any ties to the National Socialist tradition.

The nine chapters of this book have explored the manifold ways in which this Romantic fiction develops, unfolds, and manifests itself, and have illuminated them from different perspectives. My investigations also demonstrate the remarkable persistence and equally remarkable malleability of the discourse on Nordic myth. Its individual elements, which I have discussed at length in this book, have been astonishingly stable since their inception and their more systematic compilation in Romanticism. They have also inspired various movements and ideologies from quite different sides of the political spectrum, and they have become productive in the arts, in music, literature, and religious thought in various eras and contexts. 
As I struggle to complete this fragmented collage of a conclusion, a small text by Birna Bjarnadóttir comes my way, entitled a book of fragments. ${ }^{2}$ The author is an Icelandic literary critic who for the last ten years has chaired the only Icelandic studies department outside of Iceland, in Winnipeg, Manitoba, the location where a large group of Icelandic immigrants settled in the late 19th century. Her short text circles around the past and present connections between Iceland and Western Iceland, as this part of Manitoba is referred to. The book locates these connections firmly in European historical and contemporary global contexts, weaving together themes, motives, and images that have shown up in the book you hold in your hands now, including German Romanticism, (Icelandic) nature, religion and conversion, aesthetics and its decline, pictures from films, and more. But maybe it does not really weave them togther, but rather lets these strands and ribbons of thought blow in the wind. They tangle and untangle, forming unstable patterns of unexpected beauty. And they elicit skepticism.

The foreword of the book, written by Winnipeg film scholar George Tole, reflects on the beauty and effects of the fragment. Together with Birna Bjarnadóttir's fragments, his text brings to life the aesthetic revolutionary spirit of the early Jena Romanticists, as well as a contemporary search for "connection, fuller belonging."3 Tole finds a Zen-like quality in these Romantics' life and writings. In Birna Bjarnadóttir's texts, their experiments with love and togetherness, and their 'symphilosophic' literary experiments connect with Old Norse saga literature, especially with the figure of Sigurd from the Völsunga saga. She associates his desire to be taught "mighty things," and his tragic, yet necessary, forgetting with contemporary twenty-first century sentiment. "There is no eternal bliss in sight. The knowledge gained is also knowledge lost." ${ }^{4}$ Tole elaborates on this in his foreword:

Bjarnadóttir knows better than Sigurdur that we are meant to forget [the mighty things] as soon as we begin to grasp what they are. Or if we are not meant to, that we almost surely will. Let us be forgiven each and every time for our need to know and our need to forget. With any luck we will come round upon these 'mighty things' again, as though (always) for the first time. ${ }^{5}$

\footnotetext{
2 Birna Bjarnadóttir, a book of fragments (Winnipeg, M B: KIND Publishing, 2010).

3 Tole in ibid., xviii.

4 Ibid., 61.

5 Tole in ibid., xviii.
} 
Has this book done the same, just the other way round? Have I written it so that the dark sides of the Romantic constellation and of the tradition of Norse myth will not be forgotten? And if we remember those, do we lose the 'mighty things' (whatever they might be) once and for all? Birna Bjarnadóttir writes a fragment titled "rivers full of gods":

Where she comes from, the rivers are full of gods. When the conversion to Christianity took place, they threw the Nordic Olympus into a waterfall, knowing that whatever happened in life, the old religion would be passed around the table. Christianity was never a threat, nor was any other religion for that matter. ${ }^{6}$

I wonder if there is a way to pass the gods around the table all the same - albeit never an unambiguous one? I somehow still doubt it. Yet, I don't know.

The problem remains that the discourse on Germanic myth, as I have demonstrated, has always been dependent on the idea of national, racial, or ethnic essences. In order to read the mythological sources as messages from a preChristian era, one has to employ these ideas of ethnic essences. Therefore, any attempt at a mythological revival will necessarily be tainted by essentialist operations. This is also true for the diverse artistic appropriations of this discourse on Nordic or Germanic myth, to the extent that they take the idea of a principally accessible pre-Christian past as their starting point. In this sense, the discourse and its religious or aesthetic actualization can never be innocent. The gods passed around the table will always carry with them a tinge of nationalism, racism, or ethnic and cultural essentialism. This is why an elective affinity between this discourse on Nordic myth and right-wing thought is always immanent - a connection that can never be completely eschewed by well-intentioned a-racist Heathenism.

The problem lies in the temptations attached to this discourse on myth, a discourse which has itself turned into mythology: Romantic aestheticism; ideas of creative unfolding; a less alienated, more authentic life; a sustainable life at peace with what is seen as 'nature.' In keeping these yearnings alive, we keep the gods alive, or vice versa: keeping the gods alive promises to keep us tied to these yearnings.

But does a historical-critical engagement with mythological sources really have to lead to a merciless disenchantment of the world of Nordic myth? Again, the answer would be 'yes' and 'no.' Yes, in the sense that it would mean one has to acknowledge that the 'beliefs of our ancestors' prior to the advent of

6 Ibid., 31. 
Christianity necessarily remain obscure, inaccessible due to a lack of valid sources. No, in that a historical-critical approach can open our eyes to fascinating and creative medieval engagements by Christian writers in the North, with their own imaginations of their forefathers' lives and beliefs, as well as to the continued productivity of such engagements. Moreover, it can also open our eyes to the fact that these engagements are entangled in their own ambiguities and political agendas, i.e., that they themselves have probably contributed to laying the ground for the essentialist thinking criticized in this book. 